\title{
Some Migdols of Palestine and Egypt
}

\section{Joseph Offord}

To cite this article: Joseph Offord (1920) Some Migdols of Palestine and Egypt, Palestine Exploration Quarterly, 52:1, 23-29, DOI: 10.1179/peq.1920.52.1.23

To link to this article: http://dx.doi.org/10.1179/peq.1920.52.1.23

曲 Published online: 19 Jul 2013.

Submit your article to this journal $x$

山 Article views: 14

Q View related articles $\sqsubset$ 


\title{
SOME MIGDOLS OF PALESTINE AND EGYPT.
}

\author{
By Joseph OFFord, M.R.A.S.
}

IN an essay by M. George Daressy, fortunately called forth by Sir William Wilcox's theories as to the geography and itinerary of the Hebrew Exodus, the author explains his views-and they are those of most Egyptologists who read the old Egyptian writingsas to the route taken by the immigrants both within and immediately beyond the then Egyptian north-eastern frontier. ${ }^{1}$

In the course of M. Daressy's remarks he mentions that the ancient records disclose the existence in Ramesid times of at least three sites between the mouth of the Wadi-Tumilat and Suez which were known as Migdoks. This need not be considered strange, because along a line practically coincident with that of the Suez Canal was the boundary between the Egyptians and the Semites of Asia. Across it was a constant flux of the two races, and in Joseph's time the foreigners had been lords of the Delta, and departing had doubtless left some of their vocabulary behind them.

Migdol is the well-known Semitic word for a watch tower, and it was one of numerous words taken over into the Egyptian. Such was shakaua, "a well" or watering place, doubtless derived from the same root as Hebrew shakah, "to drink." The Egyptian for a chariot, markabuta, is also clearly an immigrant by the Nile from the Semitic speech.

- The author of Exodus, we may be certain, could have used the old Egyptian title for a watch tower had he chosen, because, as has been pointed out previously in these Archaeological Notes, he knew Egyptian well. For instance in Exodus ix, 10, he gives its term aba'bu'oth for boils.

The way taken by the Israelites being a march to and a crossing of the frontier, they naturally passed some of the interspersed boundary Migdols, and we find one of these mentioned in the

1 For Zaru tho Igyptian for Zoar, a frontier post, soe a scarab of Rameses II relating to the equipment of the fortress, a superior Migdol (now at Moscow). Turiaeff, " IEgyptokii Zamyetki," Bulletin Ruse. Aoad. Sciences, 1916. 
Exodus narrative. As Moses no doubt correctly anticipated, if the people took the main Mediterranean route to Syria, upon which they would almost certainly be intercepted, and along which probably there were more and stronger Migdols, perhaps the fugitives going by the Sinai trail did not come in sight of many such posts.

The Migdol mentioned in Moses' story of the march would not be identical with that in the Old Testament passage, giving the popular form of the words and depicting the extreme north to south extension of Egypt as being "from Migdol to Syene," a colloquial phrase, equivalent to the Hebrew "from Dan to Beersheba," or our own words "from the Himalayas to Cape Cormorin." This last Migdol was the northernmost, partly seaward and partly landward, protecting and observatory tower with its warders and outlookers situated upon the Mediterranean shore near the modern Port Said. Its guardians could detect the approach of persons from Syria by the main coast road, or of mariners, friend or foe alike, by sea, and signal accordingly to their neighbouring Migdol towers.

In Hebrew a Migdol was not always, strictly speaking, a watch tower for detecting undesirables-thieves, pirates, brigands, runaway alaves, and so forth-but also a look rout place for farmers and pastorals, to detect birds destroying their crops, and animals such as foxes. The Flock Tower, Migdol-Eder of Geneses, would be one of these, similarly the Vineyard Migdol of Isaiah v, 2, whose value may have specially lain in the way of foxes and birds. The Exodus Migdol and the three discovered in Egyptian records near the frontier on the outward route from Goshen were military Migdols. A Hebrew author with poetic fancy used as a metaphor both purposes, and we quote him because it illustrates so aptly the anticipation that these imperfect essays upon the archaeology of Palestine and her neighbouring peoples may explain much in the Bible that is insufficiently appreciated by many people. "And thou, towor of the flock, stronghold of the daughter of Zion" (Micah iv, 8).

Palestine possessed many villages bearing the name of Migdol, they having probably sprung up because sheltered by some watch tower with its little garrison that had been enlarged and fortified. Thus Migdol-Gad and Migdol-El, of the patriarchal times, are two towers, differentiated by having, in the one case, the word "Fortune," a Canaanite or Amorite deity-name, and in the other El, " the tower of God," attached to them. Mary Magdalene came from a Migdol village, and therefore to use this word, originally meaning a tower 
or observation post, as a title for a South American river is to perpetuate a misnomer. Brugsch quotes a record of a victory by Rameses the Great at some Migdol in Palestine or Syria.

So intimate were the relations between Palestine and Egypt that hieroglyphic texts mention Syrian Migdols, because in war time the royal troops, and in peace times their plenipotentiaries and king's messengers on their journeys, halted at places bearing the name. Thus, the catalogue of Palestine places upon the temple wall at Medinet Habou mentions a Mektol (־). M. Daressy says it was probably a castle tower attached to the Medjel between Yutta and Essemona (Recueil de Travaux, 1899, p. 33).

The Roman Antonine Itinerary mentions a Magdola as a placename some twelve Roman miles south of Pelusium. This may be the very Migdol meant by Jeremiah when he wrote the words from Migdol to Syene. It should also be the Magdolos of Hecateus of Miletus, as quoted by Stephanus of Byzantium, unless Migdols (or rather Migdolim) were studded along the Syrian shore, similar to Martello towers upon our Kentish coast subsequent to the Napoleonic wars. ${ }^{1}$

The situations of Palestinian Migdols leads up to an exceedingly interesting geographical question relating to the true position somewhere' north, of the boundary known to the Jews as the "river of Egypt," the answer to which will perhaps clear up what has hitherto been an undecided historical matter.

The sudden fall of the Assyrian Empire was achieved, after the gradual decline of its power, by a military disaster in Syria. The cuneiform inscriptions are commencing to throw light upon the subject, but attention here will be confined to the Hebrew and classical records. Herodotus tells us that the "Syrians" were fought by a Pharaoh named Necho in a battle at Magdolos, and were there defeated. After this victory the Pharaoh took Cadytis, a great Syrian city. In gratitude for his triumph Necho consecrated

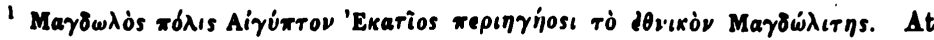
Toll el-Herr, which M. Clédat rockons to be 18 kilometres south-west of Peluoium, betwoen the Suez Canal and Farana, he dug up coins inecribed "Year IV of the independence of Ziou." These are probably pieces of the Aomonean Maccelees. Their presence ouggests this being the Jewish Migdol of Jeremiah, and it may also be the Migdol of the Tell el-Amarna tablets (see further abore), and the Magdolo of the Antonine Itinerary, though perhaps not Tell es-Bamut. 
to the god Apollo in that deity's temple at Brauchidae the uniform he wore at the battle. The prophet Jeremiah had a great deal to say about Necho in his chapters xlvi and xlvii. In the latter he records the taking of Gaza (Cadytis) and that of its neighbouring city of Askelon (the Askaluna of the Egyptian and Tell el-Amarna. records).

This battle of Magdolos has hitherto been carelessly identified with the engagement at Megiddo, described in the second book of Kings, at which Josiah, king of Judah, was slain fighting against Necho II. It can be admitted that there may have been a Migdol tower near to this Megiddo, but the words Megiddo and Magdolos (Migdol) can never be identical. Moreover Megiddo was away to the north, nearer Carmel, and the Egyptian army having as enemies both the Assyrians and Hebrews would not be likely to risk an engagement there until Gaza, in their rear, had been surrendered. ${ }^{1}$

Furthermore, we are too much accustomed, because of our interest. in Palestinian history, to attach undue importance as world history to events occurring within the duration of the Hebrew kingdoms. The defeat and death of Josiah would not be considered by a Pharaoh, who ventured to measure his power with that of the mighty Mesopotamian Empire, as sufficiently an evident act of interposition by a divinity to justify his making a special votive offering, of a nature particularly appropriate for the commemoration of the event, to the temple of a non-Egyptian god.

The duplicate account in Chronicles says that Necho was marching to attack the Assyrians at Carchemish when the fight in which Josiah fell took place. This would be quite an insignificant engagement compared with what a battle between the Egyptians and their foreign troops and the Mesopotamians must have been. This statement that distant Carchemish far from their base was their objective is corroborative evidence that Gaza and the Phoenician Philistine maritime cities with their fortified islands must have been captured before such an extended expedition would be attempted.

The statement as to the king having offered to the shrine at. Brauchidae is especially to be credited because Herodotus was quoting. Hecateus of Miletus, who was a person who could frequently visit that temple, and so probably knew the very sentences of some

1 This theory as to Magdolos was proposed by M. T. Rainsch some thirty Jeare ago, and objeoted to by Oppart who claimed that Cadytis was Canchomish. 
inscription recording the gift, if it was displayed in the edifice; or he might know the contents of any letter that accompanied the armour, or uniform, that the priests had preserved among the temple's records. The cause of the Pharaoh sending his thank offering to Brauchidae was doubtless that in the Egyptian army there were Ionians, or Carians, indeed perhaps both, serving as mercenaries; for the Egyptians at all times of their history, as far as we know it, employed foreign troops. Carian inscriptions have been discovered as graffiti upon Egyptian monuments proving decisively that such Asiatics were stationed in Egypt, but they do not preserve the date when they were written. ${ }^{1}$

It may be objected that, whilst this view that the battle of Magdolos was not identical with that of Megiddo may be correct, it was not an Assyrian defeat because Herodotus calls Necho's foes "Syrians," and elsewhere he properly names as Assyrians, armies derived from Mesopotamia. But in this special instance Herodotus was probably copying Hecateus, who quite possibly, by the shorter term, meant the Assyrians. ${ }^{2}$

Moreover, it was an Assyrian army in Syria that Necho defeated. Under Esarhaddon and his successors, Syria and part of Egypt were beneath Assyrian sway. As its power diminished and Babylon was lost to them, Necho freed Egypt, for Berossus says he was a Satrap who rebelled. When the Medes still further weakened Assyria, Necho determined to capture the Palestine coast cities. The Magdolos victory secured Gaza and Ascalon (see Jer. xlvii). Doubtless Ashdod also, for Sargon had placed a garrison there. "Every helper that remaineth," that is the Assyrian forces in the coast cities, was to be "cut off from Tyre and Sidon."

'The fall of the fortresses consequent upon the victory of - Magdolos should be dated about 609 B.C. Then, with his base secure, Necho II ventured to "go up against the king of Assyria, to the river Euphrates" (2 Kings xxiii, 29), and Josiah, against prophetic advice, foolishly tried to intercept the Egyptian forces. The Old Testament and Herodotus are thus jointly confirmatory. As to the question at which of the several Migdols the battle took place, certainty is not yet attainable. The Meidjdal near Ascalon

1 The owner of immense mass of pepyri of Zeno, a Oarian (? Greek), found in Iigypt lately is of interest in this respect.

2 Herodotus, VII, 63, mentions that eome Greeks term as Byrians what really mare Asoyrians. 
would appear to be the most probable place. If it was the Migdol south-west of Pelusium, then the Assyrians must have advanced towards the Egyptian frontier to await Necho's assault. The memory of Necho's victory mày have been dimmed by his disastrous defeat at Carchemish by the Babylonians after their conquest of Nineveh had given them supremacy in Mesopotamia.

As explained in a former paragraph, the Semitic word Migdol was adopted into the Egyptian vocabulary. The instance of the Latin Castra, which became the English Chester and forms the penultimate syllables of so many British city names, is an analogy. The accoptance by Egypt of this alien word, it may be supposed, preceded the time of the composition of the well known papyrus text in which a scribe of conservative sentiments bitterly laments the usage by youthful "chic" Egyptians of numerous Semitic words unworthy of incorporation into their superior mother tongue. The word, apparently, was changed from its real original pronunciation, because town names which we transliterate as $M a-k$-to-ra and $M a-k$-ti-ra represent the word. In one of the Anastasi papyri, two runaway slaves are reported to have succeeded in crossing the frontier to the northeast by passing through the wall at (or of) the Ma-k-ti-ra or watch tower of Seti I. This place would be in the Eastern Delta somewhere north of Kantara. Jeremiah says Jews resided in Egypt at Noph (Memphis), Tahpanhes, and Migdol, apparently naming places from south to north. Brugsch Pasha gave a text of Amenophis, most interesting because of its similarity to Jeremiah's words, which he renders: "From Migdol (Samut) as far as Syene on the frontier of the Land of Cush."

The Egyptian Migdols existed in the pre-Mosaic period, because Tablet 57 of the Tell el-Amarna collection says : "Behold, Acco is like Migdol in Egypt, and let not the king permit these men (the, enemy) to oceupy the city." This signified that Acco was a fortress of strategic value like one of the Migdols in the Delta. Two Syrian towns named Migdol also occur in Tablets 232 and 281.

In Egypt, as time passed by, the Migdol title became scattered about the country, precisely as many towns in Greece were named Ephyra (watch tower). This is proved by numerous Graeco-Roman papyri, especially the series of such documents from Tebtunis. Papyri 80, 81 and 82 from thence concern a village called Magdola, which was situated upon the site of the present Medinet Nahas, in the Fayoum. 
M: Jouguet has published several papyri and two ostraca from a place called Magdola, the same site probably as that mentioned in Grenfell and Hunt's Fayoum Towns. A Demotic papyrus of the time of Ptolemy Philadelphus, to be found in an essay by Mr. Griffith in the Proceedings of the Society of Biblical Archaeology, 1901, concerns a Magdola near Thebes (i.e., close to the Noph of Jeremiah). There is one much earlier mention of a Maktol than these, because it is of about the date of the Exodus. This was in the Sethroïte Nome.

The common use of the word in Egypt in Graeco-Roman times is indicated, because among the almost innumerable imposts with which the later Egyptians were burdened, was one for the upkeep of the village or district Migdols. These may have been observation posts for fires, as well as for bedawin incursions, and warnings of locust clouds, and so forth. Among the officials there were

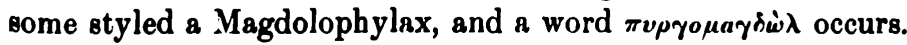

\section{NAZARETH. \\ A FORGOTTEN PAGE OF ENGLISH HIBTORY.' \\ By Estiblie Blyth.}

IT has been truly said of Palestine that every foot of her soil has its history. A land without a people, she is the mother of the world and all its peoples are her children; there is not one race that has not its holding in her, not one country but has striven to give or gain glory within her narrow limits.

We English have bonds with Palestine that are peculiarly strong, roots of kinship that reach very deep, a sympathy in our common history that binds her a little closer to us than to the reat of the world. The more we study the history of either land the more deeply are we impressed by this curious fact. We do not sufficiently recognize the importance of this fact; we are so much accustomed to the massive structure of England's greatness that we take it as a

1 From the United Service Magasine, Dec., 1918, with the kind permiseion of the publishers, Mossrs. Clowes and Sons, Ltd. 